\title{
IAPP wt Allele
}

National Cancer Institute

\section{Source}

National Cancer Institute. IAPP wt Allele. NCI Thesaurus. Code C112880.

Human IAPP wild-type allele is located in the vicinity of 12p12.1 and is approximately 25 $\mathrm{kb}$ in length. This allele, which encodes islet amyloid polypeptide protein, is involved in the modulation of insulin-stimulated glycogen formation. 